\title{
THE THERMAL PERFORMANCE OF MOSQUE WITH DOME ROOF AND TAJUK LIMASAN (Case study: Ottoman Mosques in Turkey and Java Mosques in Indonesia)
}

\author{
Sugini $^{*}$, Amalia Nur Fitriani ${ }^{2}$, Fahrun Reza Anggoman ${ }^{3}$ \\ ${ }^{1,2,3}$ Architecture Department, Civil Engineering and Planning of UII, INDONESIA \\ "Corresponding author; Email: sugini@uii.ac.id
}

\begin{abstract}
The purpose of this study are: (1) Analysing the thermal quality of the mosques which use dome and Tajuk \&Limasan roof especially seen on the thermal pattern and behavior; (2) Knowing how high a proportion of openings may affect the quality of the indoor thermal. The study was conducted on the mosques in the two regions with different climates. The objects of research are (1)the Great Mosque of Banten, (2) Great Mosque of Yogyakarta,both of them located in Indonesia and(3) Sehzade Mosque , (4) Mihrimah Mosque, located in Turkey. Data were collected by observation and secondary data. For the first purpose data is processed into information about: (1) thermal quality in space, (2) the pattern of thermal comfort, (3) the distinctiveness of the pyramid roof and dome. For the second purpose, the measurements of the openings dimensions, temperature and humidity are done. In addition, the macro climate secondary data per year in each city are collected indirectly. Data processing is done by calculation, use the chart manually and using software Autodask Ecotect. The results of this study are as follows: (1) Tajuk \& Limasan-roofed mosque had more varied radiation temperatures in each month, while the dome mosque has relatively stable. Tajuk\& Limasan-roofed mosque has a homogeneous heat distribution across the roof. As for the dome-roofed mosque, spreading tends to diffuse; (2) the proportion of openings is more influential in the mosque located in the tropics (the Great Mosque of Banten-Indonesia) compared to the mosque located in a temperate climate (Sehzade Mosque-Turkey).
\end{abstract}

Keywords: Thermal comfort, roofing tajuk (pyramid), limasan and dome, proportion of openings, tropical-temperate climate.

\section{INTRODUCTION}

Mosque is the main place for praying for Muslim all around the world. The main function of mosque in the community is as the center of routine religious activities such as Islamic discussion, preaching, and madrasah or education for child and teenagers (Shukri, 2010). Mosque develops along with the expansion and spread of Islam in the world, starting from the Middle East, Andalusia, Asia, Europe, until Nusantara. This development also brings some impacts to the architecture uniqueness of mosque in the Middle East such as mosque in Iraq with its onion dome, mosque in Turkey with its half globe, and mosque in Indonesia with its pyramid roof (Wikipedia, 2016).

Since the mosque functions as a medium for various vital activities for Muslims, the comfort aspect inside the mosque becomes the factor that should be considered to support the good atmosphere for praying. A good building is a building that can provide physical and psychological comfort to the user. The factors that determine the comfort ranges from external (environment) and internal (biological) factor. In the discipline of architecture, the deter- minant factors is more focused on external factors that include the building itself and the influence of both natural and artificial environment based on the context of the building location and position.

Meanwhile, intellectuals and perceptual performance of human beings will achieve the best condition when the human is in a thermal comfort condition (Fanger, 1982). Thermal comfort inside the mosque is one of factors that determine the success of a mosque that should be considered because good body condition is needed by each individual in running the religious ritual especially in doing the prayer that requires high concentration and peacefulness.

The first object of the research is located in Indonesia in the coordinate of $6^{\circ}-11^{\circ}$ latitude and $95^{\circ}$ BT $-141^{\circ}$ longitude, between Pacific and Indian Ocean in the meeting point of two mountainous series i.e. Pacific and Mediterranean Circum. Indonesian is located at the equator line with tropical climate that has two seasons in each year (Wikipedia, 2015). Indonesian with its diversity of culture should have special technique in controlling the thermal space inside tropical building. It is reflected in the variation of traditional building shapes in every area in 
Indonesia. In traditional building, the climate factor that influences the thermal comfort is arranged in such a passive way to achieve thermal comfort without using electrical power excessively. One of traditional buildings that that still survive and sustain is Javanese traditional building. One indicator of the successful design of the building is efficient and economical use of energy especially in thermal controlling and natural illumination (Widayanti, Suparman, \& Sekarsari, 2012). The buildings that become the sample of tropical building in this research are Mosque Agung in Banten and Mosque Agung in Kauman, Yogyakarta.

The next research object is located in Turkey in the geographical coordinate of $39^{\circ} 00^{\prime}$ latitude $35^{\circ} 00$ longitude. Turkey shares border with the Black Sea between Bulgaria and Georgia, and Aegean and Mediterranean Sea, between Greece and Syria (Wikipedia, 2015). Turkey has a fair climate with four seasons in each year. The traditional mosque has the characteristics of mosque in modern period that presents the type of mosque with field, dome, and madrasah. The leading figure in the period is Sinan the Architect that designed hundreds of mosque in Turkey. At that time, mosque was built as the symbol of power and authority of the rulers. The symbols are indicated with a large-scale mosque with the magnificent of its shape and materials (Susanawiyah). Every detail of building aspect from the work of Sinan has been calculated well including the thermal and acoustic aspect that is controlled by insulation in the dome (Yildirim, 2014). Meanwhile, in the opening side, the configuration of symmetrical opening is following the facade shape of the mosque. Mosque Sehzade and Mosque Mihrimah are traditional mosque from the work of Sinan that become object of this research. In addition, the researcher considered that two mosques can represent other traditional mosque in Turkey. Both mosques were chosen based on the scale of the building that is similar with two samples of mosques in Indonesia.

The research is focused on the main body element of the mosque that is the roof and the opening of the mosque. The first discussion is about the thermal quality of mosque is using the dome (case study on Mosque Sehzade and Mosque Mihriman of Turkey Sultanate) and mosque using the roof of Limasan or pyramid (case study on The Great Mosque of Banten and Mosque Gede Kauman Yogyakarta). Afterward, the study will discuss the role of opening for thermal comfort in the main space of the mosque as the center of activities with case study on The Great Mosque of Banten and Mosque Sehzade. The analysis will further discuss the effect of shading part of the Mosque (both dome and limasan or pyramid) toward thermal quality of the building.
The next discussion will compare the proportion of opening towards the success level of thermal comfort in each mosque in order to identify the model of relations between two variables. Finally, the conclusion of this research can be used as guidance to design building in the area with tropical and medium climate.

\section{Problems}

1. How is the performance of thermal comfort of mosque with pyramid and dome roof seen on the pattern and thermal behavior?

2. How can the proportion of opening influence the thermal quality of mosque main space in the tropical and medium climate area?

\section{Objectives}

1. To identify the patterns of thermal comfort and behavior of the mosque with pyramid and dome roof.

2. To measure the proportion of opening in the mosque covering that may influence the quality of space thermal inside the building.

\section{LITERATURE REVIEW}

\section{Mosque}

Mosque is building that functions as a place for praying and center of social activities of Muslim society (ummah) such as discussion about religion, learning center for Holy Qur'an reading and discussion venue for community.

Typology of mosque in Java consists of various types. The first is Javanese palace mosque. Various shapes of mosque in Indonesia, especially in Java are dominated by the shape of aslant roof with tritisan. The shape of roof shading consists of joglo, limasan (pyramid), tajuk, kampong, and panggang. Each type has its own strength from the aspect of response towards the climate such as sun radiation, sunlight, and air circulation.

The shape of shading was developed into many variations of shapes and names such as panggang pe ceregancet, kampung ceregancet, limasan ceregancet, limasan trajumas, lambing gantung, kampung semar, limasan semar, tinandhu joglo, semar tinandhu, tajug semar, tinandhu kampang, lambing teplok, limasan lambing, teplok joglo, sinom tanjung semar, sinongsong lambing, gantung tajuk mangkurat, joglo hageng, and tajuk cebokan (Satwiko, 2004)

Based on the typology above, the building of The Great Mosque of Banten is included in the type of tajuk cebokan and Limasan lambing tepok while The Great Mosque of Yogyakarta is included in the type of Tajuk mangkurat shading. 


\section{Concept and Factor of Thermal Comfort}

The basic concept of thermal comfort is the accomplishment of heat balance when the number of internal heat production is reduced by heat loss because of heat vaporization through the skin and radiation of respiration and heat convection from the surface of body to the part of body that is covered by the clothes (Fanger, 1982).

Sugini (2014) concluded that thermal comfort should be seen from the paradigm of psychological adaptive thermo, in which the perception of thermal comfort is the accumulation result from not only physical or physiological aspect but also from psychological difference aspect.

Evans (1980) stated that there are four factors that can control thermal comfort namely temperature, humidity, radiation, and air movement. Szokolay (Sugini, 2014) argued that thermal comfort depends on two main variable i.e. climate and subjective factor. The climate factor includes sun, temperature, humidity, and speed of the wind. Whereas, subjective factor includes clothing, age, sex, level of obesity, health condition, type of food and drink, and skin color. However, Fanger (1982), American Standard of ANSI (ASHRAE 55-1992), and international standard for thermal comfort (ISO 7730:1994) stated that such subjective variable does not actually influence thermal comfort. Humphreys and Nicole (Sugini, 2014) stated that thermal comfort can be influenced by the adaption of each individual towards the temperature outdoor and the environment. Human beings who normally live in hot or tropical climate will have higher comfort temperature compared to people who usually live in the low temperature.

Following table indicates different opinion about thermal comfort factor:

Table 1. Thermal Comfort Factor

\begin{tabular}{|c|c|c|c|}
\hline Evans & Szokolay & $\begin{array}{c}\text { Fanger, American } \\
\text { Standard of } \\
\text { (ANSI/ASHRAE } \\
\text { 55-1992) and } \\
\text { International } \\
\text { Standard }\end{array}$ & $\begin{array}{l}\text { Humphrey and } \\
\text { Nicol }\end{array}$ \\
\hline \multirow[t]{2}{*}{$\begin{array}{l}\text { Climate } \\
\text { - temperature } \\
\text { - humidity } \\
\text { - radiation } \\
\text { - air movement }\end{array}$} & $\begin{array}{l}\text { Climate } \\
\text { - sun radiation } \\
\text { - temperature } \\
\text { - speed of the } \\
\text { wind } \\
\text { - humidity }\end{array}$ & $\begin{array}{l}\text { Climate } \\
\text { - sun radiation } \\
\text { - temperature } \\
\text { - speed of the wind } \\
\text { - humidity }\end{array}$ & $\begin{array}{l}\text { Climate } \\
\text { - sun radiation } \\
\text { - temperature } \\
\text { - speed of the wind } \\
\text { - humidity }\end{array}$ \\
\hline & $\begin{array}{l}\text { Subjective } \\
\text { - Clothing } \\
\text { - Acclimatization } \\
\text { - age and gender } \\
\text { - level of obesity } \\
\text { - level of health } \\
\text { - type of food } \\
\text { consumed } \\
\text { - skin color }\end{array}$ & $\begin{array}{l}\text { Subjective } \\
\text { - Activities } \\
\text { - Clothing }\end{array}$ & $\begin{array}{l}\text { Subjective } \\
\text { - Activities } \\
\text { - Clothing } \\
\text { - Individual adap- } \\
\text { tation } \\
\text { Geographical } \\
\text { Location }\end{array}$ \\
\hline
\end{tabular}

Based on the table above on climate aspect, it can be concluded that the main factor of environmental condition that determines the thermal comforts are temperature (ta), relative humidity, velocity of the air (v) and Mean of Radiant Temperature (tmrt).

\section{Climate}

Internal comfort is influenced by climate factors such as velocity of air in the room, outdoor temperature, relative humidity of the room, sun radiation, etc. (Sugini, 2014; Widayanti, Suparman, \& Sekarsari, 2012).

Indonesia is located in the area with humid tropical climate. The main characteristic of such climate is relatively hot air temperature, high sun radiation intensity, and high level of air humidity (Soegijanto, 1999; Satwiko, 2004). The problems that emerge are the condition of outdoor temperature is higher than the standard of thermal comfort needed inside the room. Thus, the suitable effort that can be conducted in controlling thermal in tropical area is cooling system in both the building (building cooling) and the user (body cooling). Whereas, Turkey is located in the area of medium climate with four seasons so that it will experience the phase of hot and cold extreme temperature in certain period. Thus, the effort for thermal controlling is done by reducing the temperature variation peak (Koenings et al., 1973).

Climate is the average condition of weather based on long time and space for certain location in the earth or other planet. The climate in a particular place in the earth is located by the geographic and topography of the location.

\section{Opening}

According to Sugini (2014), the climate of internal room is formed by opening, building envelope, and site engineering. Thus, it is also stated that the window opening has four elements such as dimension, orientation, position, and opening element. The opening elements determine how the element in the engineering considers the sun and the wind.

\section{Window Dimension}

Window dimension should be able to control radiation and fulfill the need of space for wind so that the variables of thermal controlling is related with the climate and it can support the thermal comfort optimally (Sugini, 2013)

Brown (1994) stated that the proportion of inlet opening will determine the wind velocity. The sizes of opening towards the wide of floor may result on particular emission of the heat (Brown, 1994). 


\section{Orientation and Position of Window}

Orientation is the direction of the opening face towards direction while the position is the vertical position towards space and other mass elements. The orientation of opening is expected to control the quantity and quality of sun radiation that enter the room, to create the behaviour of air movement in the room (convection heat transfer), and to show the potentials and obstacles of view site and its environment. The orientation refers to the calculation of sun movement direction (azimuth, altitude and the angle where the shadow fall in the site), wind rose that shows the direction and the wind velocity in the site, and topography and artificial element inside and outside the site (Sugini, 2013). According to Brown (1994), heat loss can be reduced by choosing the right orientation. In winter, radiation mostly happens in the surface that is facing the south (Brown, 1994). Therefore, Mosque Sehzade and Mihrimah ideally have bigger proportion from the other side of façade to get the heat from sun radiation in the winter.

\section{RESEARCH METHODOLOGY}

\section{Location and Object of Research}

The buildings that become the research object are four mosque building in two countries with different climate, which are Indonesian and Turkey.The samples of building in Indonesia are Great Mosque of Banten and Great Mosque of Yogyakarta. The Great Mosque of Banten is located in Banten Province in Serang City. This mosque is built in year of 1566. The size of building is around $1368 \mathrm{~m}^{2}$ and the land size is $20.000 \mathrm{~m}^{2}$.

The research samples in Turkey are Mosque of Sehzade and Mosque of Mihrimah. Mosque of Sehzade is located near from District Fatih, Istanbul Turkey. It was built in 1543 by Architect Sinan. Its room is around $\pm 1600 \mathrm{~m}^{2}$ facing to southeast. This mosque has Ottoman architecture style indicated by its big dimension rock material and its dome roof. The opening in this mosque is also using traditional Turkish architecture with big dimension in each unit of opening. It is geometric and it tends to have similarity in each side of the façade. During winter, the main room of the mosque is equipped with room heating system along the sajadah or sujud location. However, this research will analyze the building without including input heating system on the software.

\section{Sampling Method and Data Gathering}

Sampling method is conducted in five stages, as follows: 1) Observation is completed with questionnaire to the mosque visitor; 2) Measuring the dimension of opening in the interior façade using CAD; 3) Inputting the data to Microsoft Excel; 4) Inputting all the data to ECOTECT software to obtain data about temperature per point of sample and mean radiant temperature; 5) Comparing the temperature per point with thermal comfort standard to identify the success level of thermal quality in each main room.

The data gathering of observation in Mosque Sehzade and Mosque Mihrimah was conducted during winter, while data gathering in The Great Mosque of Yogyakarta and The Great Mosque of Banten was done during rainy season. The determination of sampling point is based on the consideration of surveyor about critical point in the sample room. There were five points that become the sample. Four points are each located in every side of mosque façade and one is located in the main room of the mosque.

Analysis was also conducted using the software of Ecotect. At this stage, climate data that entered into the data system is based on month of the year. Due to the limitation of observation and information, then the kind of material used in the building is adjusted with material information found in the software and half of them become the assumption of the author by still considering information that is close to the real situation.

\section{RESULT AND DISCUSSION}

\section{Thermal comfort perception of the resident toward the room}

Result from the questionnaire stated that more than $80 \%$ of the users in The Great Mosque of Banten feel comfortable with the condition of the room inside the mosque. The perception is related with the temperature comfort, air movement, and humidity. This indicated that The Great Mosque of Banten has been successful in achieving thermal comfort.

Based on perceptional data in Mosque Sehzade, it can be concluded that the visitors feel comfortable towards temperature comfort, wind and air humidity that is less than $70 \%$. This indicated that the success level of the building in Mosque Sehzade has not met the need of the users. 
Analysis on the influence of the Mosque Roof Spatial comfort pattern

\section{The Great Mosque of Banten}

Spatial comfort pattern is resulted by Ecotect analysis. Figure 1 Following is the example of the analysis. Testing setting is conducted in particular month at around $2 \mathrm{pm}$.
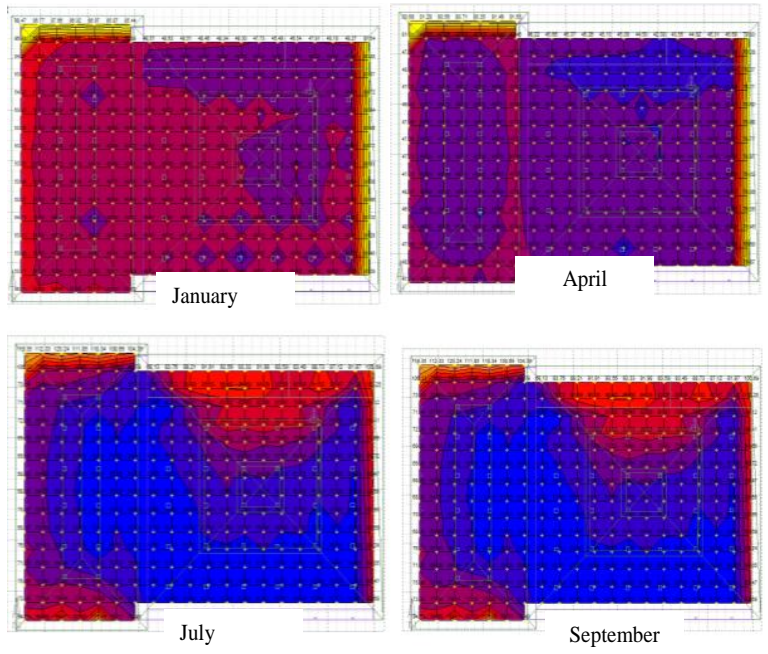

Fig. 1. Data of Radiation Temperature for the Main Room of the Great Mosque of Banten

The Spatial comfort formed in The Great Mosque of Banten actually resulted on the pattern that indicates the air domination in the room is the comfort zone $\left(19-25^{\circ} \mathrm{c}\right)$. The rest is only located in the east and southeast that has the uncomfortable range of temperature $\left(25-39^{\circ} \mathrm{c}\right)$. This is possible because the $\mathrm{s}$ east and southeast side has a very big opening or has no partition, which resulted on free sun radiation entering the space.

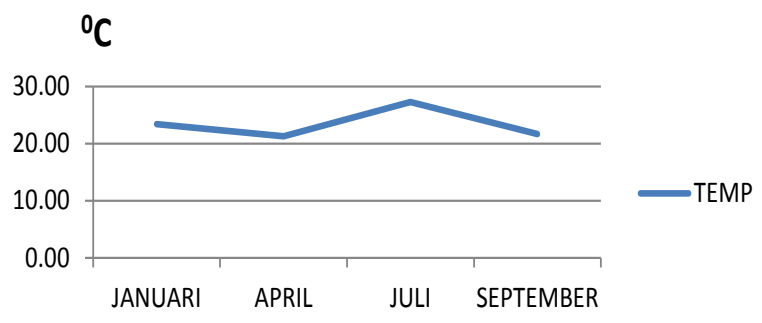

Fig. 2. The Frequency of Temperature inside the Mosque Agung Banten.

Based on the 4 month sample (figure 2), it is found that July has the highest average radiation temperature which is $27.3^{\circ} \mathrm{c}$. Meanwhile, the lowest average of radiation temperature is found on April, which is $21.3^{\circ} \mathrm{c}$.
1. The Great Mosque of Yogyakarta
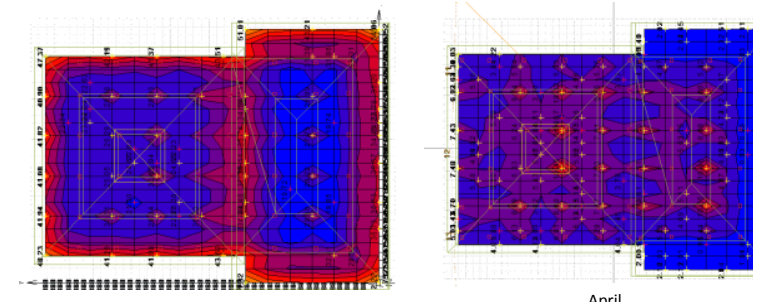

januari
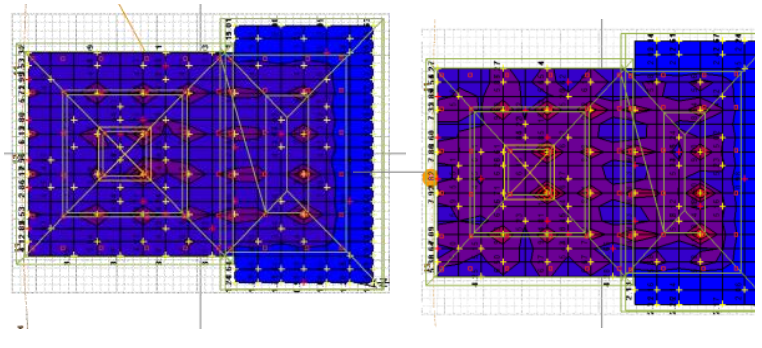

juli

september

Fig. 3. Data of Radiation Temperature in the Main Room of The Great Mosque of Yogyakarta

The Great Mosque of Yogyakarta has the design of the room that is not too different from The Great Mosque of Banten. The analysis result also indicated similar pattern. Based on the spatial comfort pattern, the temperature in the room is in the comfort zone $\left(19-25^{\circ} \mathrm{c}\right)$. Meanwhile, the rest is found in January, which indicated the temperature below comfort (25$39^{\circ} \mathrm{c}$ ). This is because on January, the angel of sunlight in Yogyakarta has the sun path with the highest declivity angle. Whereas, the sun radiation will easily enter the room in the month with the most askew angle such as in January and December. However, it is important to notice that based on the spatial comfort pattern, although in the month with inclined altitude (such as in January), most of the internal room keep giving comfortable radiation temperature performance. Nevertheless, the edge side of the room or the space 4 meter from the outer part of the room has uncomfortable radiation temperature, which is $25-39^{\circ} \mathrm{c}$.

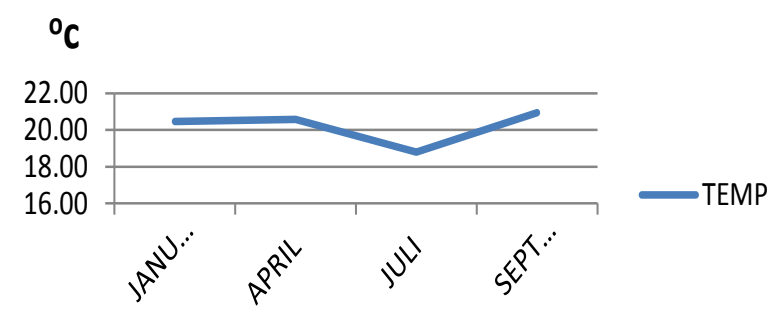

Fig. 4. Frequency of Air Temperature inside the room of The Great Mosque of Yogyakarta

Based on 4-month sample (Figure 4), it is found that July has the lowest average of radiation 
temperature that is $18.8^{\circ} \mathrm{c}$. Overall, The Great Mosque of Yogyakarta tends to have a relatively constant air temperature throughout the year.

2. Mosque of Mihrima Sultan
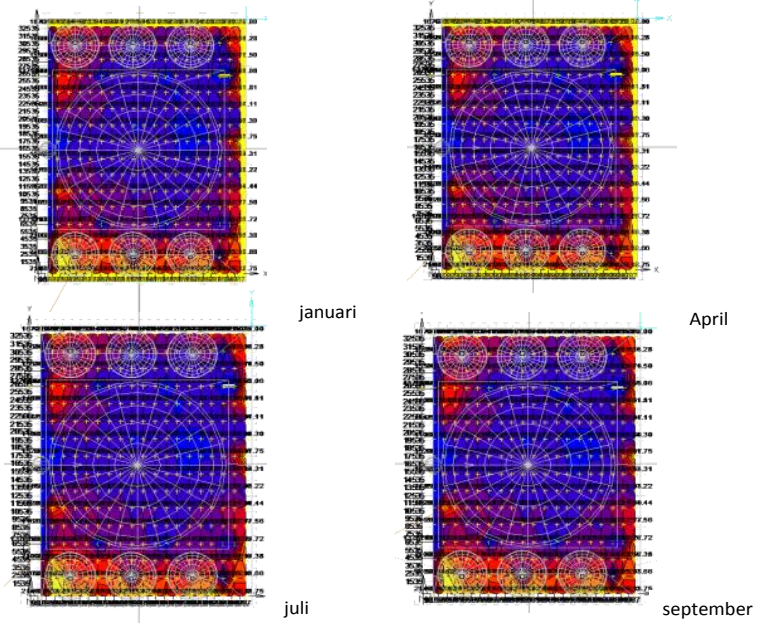

Fig. 5. Data of Radiation Temperature in the Main Room of Mosque Mihrima Sultan

Mosque Mihrima Sultan has a richer and more variational pattern of spatial comfort. This is influenced by some factors because Mosque Mihrima Sultan has so many small openings that are spread in the every part of the building including in its dome part.

From the calculation, the average radiation air temperature inside Mosque Mihrima Sultan also has significantly different temperature range. In four testing sample, it indicated that all sample show a cold temperature between $10-15^{\circ} \mathrm{c}$. Following is the specific data about the temperature difference in the four month of testing.
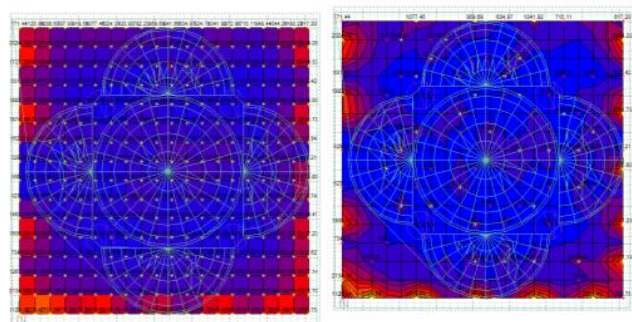

April
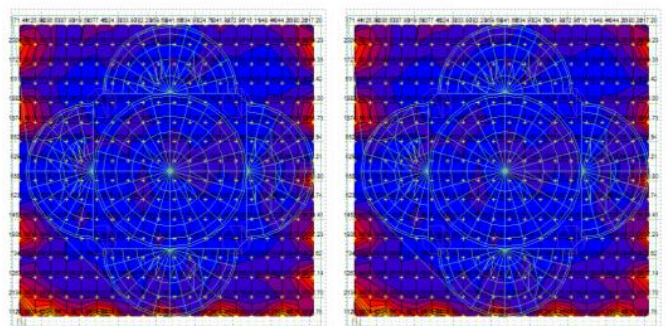

Fig. 6. Data of Radiation Temperature in the Main Room of Mosque Sehzade

\section{Mosque Sehzade}

Mosque Sehzaden has a more homogenous thermal pattern. It is because Mosque Sehzade has smaller and less openings compared to Mosque Mihrima.

From the data it can be concluded that on April, the building is able to insulate the room with less opening to keep the heat of the room. This happens in April with the average temperature of $13.6^{\circ} \mathrm{c}$. Whereas the average temperature of Istanbul City during winter is -10 up to $10^{\circ} \mathrm{c}$ (istanbultravel.com, 2015).

In other words, it can be stated that during summer (September), the Mosque can maintain to prevent the sun radiation to enter the building. This is actualized in the design that minimizes glass material with big dimension that may allow sun radiation to enter. This is proven with the average temperature in September that is only around $15.4^{\circ} \mathrm{c}$. Whereas the temperature in Istanbul City on September is around 25-35 ${ }^{\circ}$ c (istanbultravel.com, 2015).

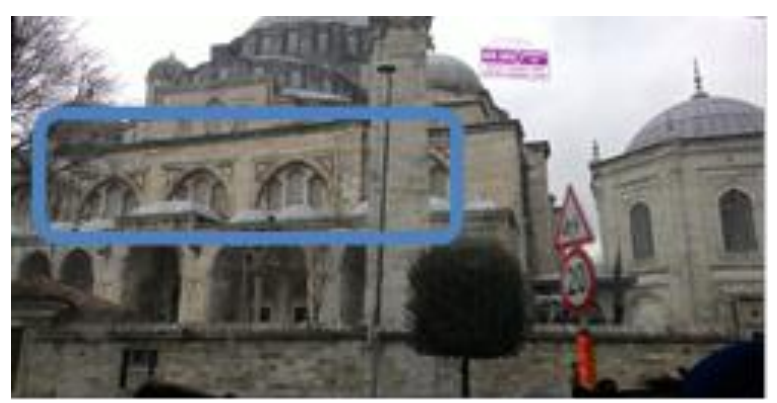

(Source: Widodo, 2015)

Fig.7. Exterior of Mosque Sehzade

\section{The Comparison of Roof Shape and the Thermal Quality of the Building}

The building thermal quality in this research is measured based on the comparison of the values in the area outside the building using the Ecotect analysis result with temperature based on the standard range compared to the total size of the room. The temperature comfort standard is $20-25^{\circ} \mathrm{c}$. The measurement result can be explained below:

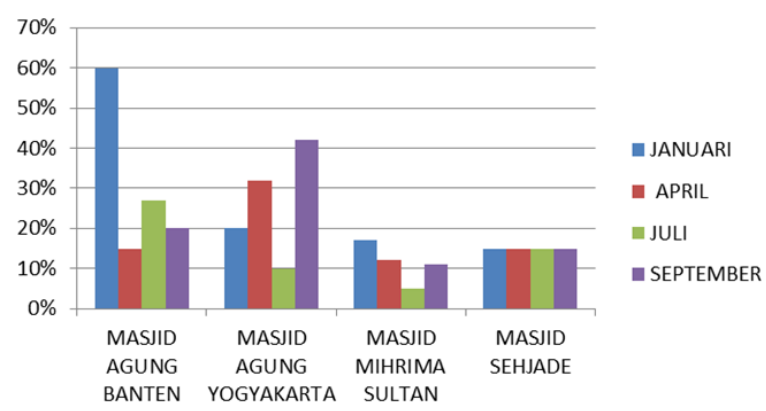

Fig. 8. The Comparison of Comfortable Air Temperature towards the Room Size 
From the data above, it can be concluded that the mosque with pyramid shading have a more variational radiation temperature in different month. Meanwhile, the mosque with dome shading has a relatively stable radiation temperature in different months.

When we observed the opening of the two kinds of mosque, the most significant difference will be seen on the opening of the roof. This kind of opening in The Great Mosque of Yogyakarta is light opening while in The Great Mosque of Banten, it is more as air opening, even though the dimension is smaller. Thus, The Great Mosque of Banten has higher percentage of room size with cooler temperature (20$\left.25^{\circ} \mathrm{c}\right)$.
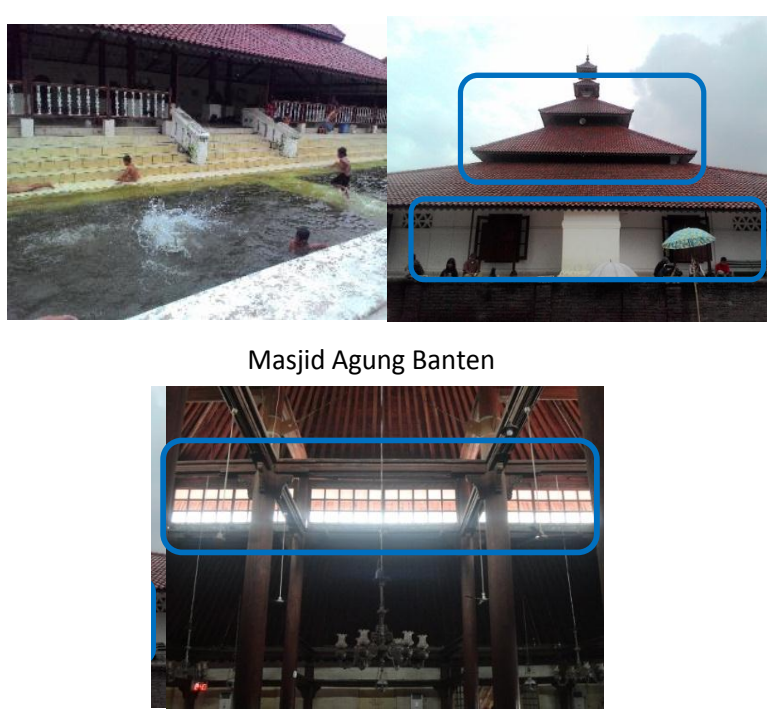

Masjid Agung Yogyakarta

Fig. 9. The Opening of the Great Mosque of Banten and the Great Mosque of Yogyakarta

From the fact above, it can be concluded that The Great Mosque of Banten and The Great Mosque of Yogyakarta has the same pattern of design but it does not fully give the same result because there are some factors that influence. One of the reasons is because The Great Mosque of Banten has more air opening compared to The Great Mosque of Yogyakarta. This makes The Great Mosque of Banten is cooler than The Great Mosque of Yogyakarta, by not considering the existence of the water pond.

\section{Special Thermal Behavior caused by the shape of Roof}

The special behavior is reviewed by making average radiation temperature in the room and by considering, the cutting angle that is then compared based on the time frequency.

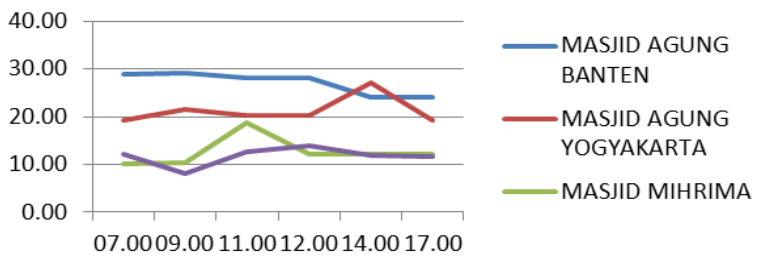

Fig.10. Average Radiation Temperature in the room with shading of Pyramyd (limasan), tanjuk and dome

Mosque with bigger light opening such as Mosque of Mihrima and The Great Mosque of Yogyakarta has wider range of air temperature in the interval of some hours. This is reasonable because with bigger light opening, when the sunlight falls in the opening angle such as window or skylight, the sun radiation will enter and significantly influence the temperature inside the building.

\section{Difference}

Another uniqueness is found in the way to distribute sunlight in the room. Limasan (pyramid) and tajuk with triangle made the sun radiation vertically enter the building so that the shape of upper part becomes homogenously hot. While in the dome roof, the sun radiation distribution is centralized so that the radiation is not distributed evenly but it is spread in the area around the dome arc.
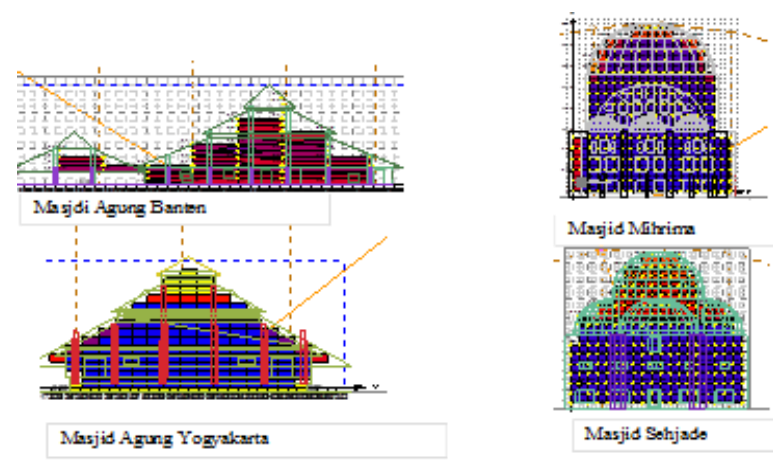

Fig. 11. Difference of Special Behavior of Mosque with the Shading of Limasan, Tajuk and Dome

From the gradation of design counter, it can be observed that the deeper a room or the further it is from the opening will make the room cooler. This is indicated with blue contour in the temperature of 10$25^{\circ} \mathrm{c}$, which is located in the central part of the building that has a position, which is further than other position towards the window and skylight.

\section{Analysis on the Influence of Opening}

Opening proportion of each mosque is differentiated based on its orientation such as north, 
west, south, and east. This is to find out how the façade that has the same proportion of opening can give different thermal comfort towards room in a building especially in the space zone around the façade.

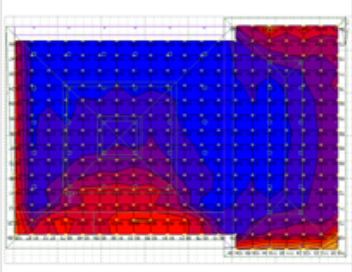

Masjdi Agung Banten

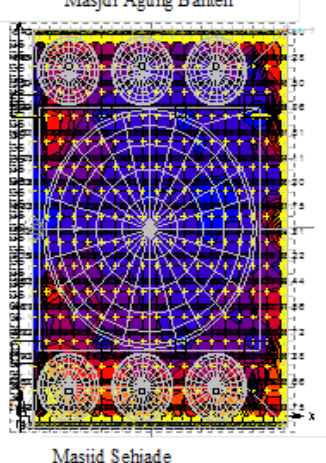

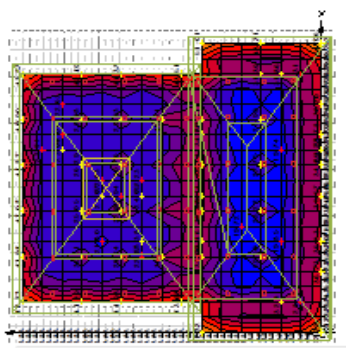

Masjid Agung Yogyakarta

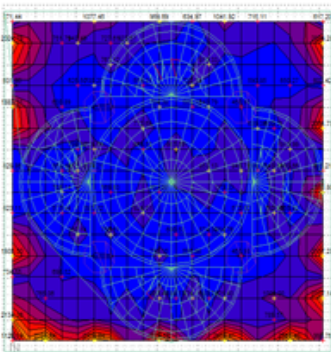

Masjid Mihrima
Fig.12. Behavior Similarity of Mosque with shading of Limasan, Tajuk, and Dome

\section{Mosque Sehzade}

\section{The Relation Pattern of Opening Proportion with Thermal Comfort Based on Opening Mode}

The analysis of thermal quality is done by using graphs that indicate differences of room temperature in three modes i.e. when the room has a closed opening, opened opening, and when the room is equipped with room cooler or heater. Following is the graph of temperature that indicates the three conditions in the hottest day in Istanbul City, which is 4 of July;

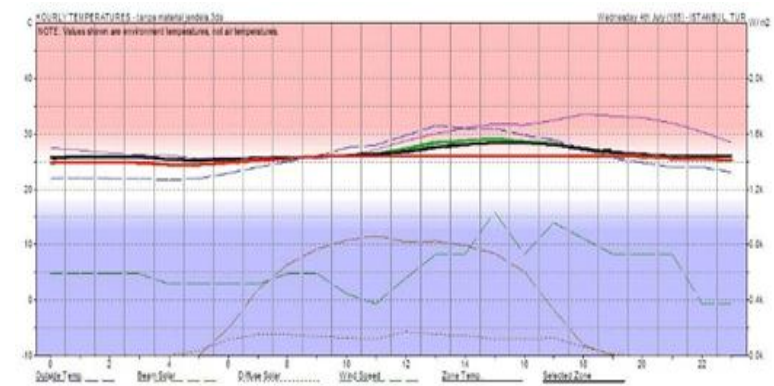

Source: Analysis from Ecotect software (update by the researcher), 2015

Fig.13. Temperature Analysis Result of Mosque Sehzade's Main Room in the Hottest Day in Istanbul
The black line indicated the condition of the room in Mosque Sehzade when the opening is closed so that the temperature detected is the radiation temperature (tmrt). The green line is the measurement of temperature in the main room when the opening is open while the red line indicated the temperature when using mode-cooling system with overall heat distribution that produce $100 \%$ comfort. The difference between opened and closed opening does not show big delta, which is only around $\pm 1.0^{\circ} \mathrm{C}$.

Based on the graph above, it can be seen that the black line is closer to the comfort condition. Thus, it can be concluded that the room in Mosque Sehzade is more comfortable when the opening is closed.

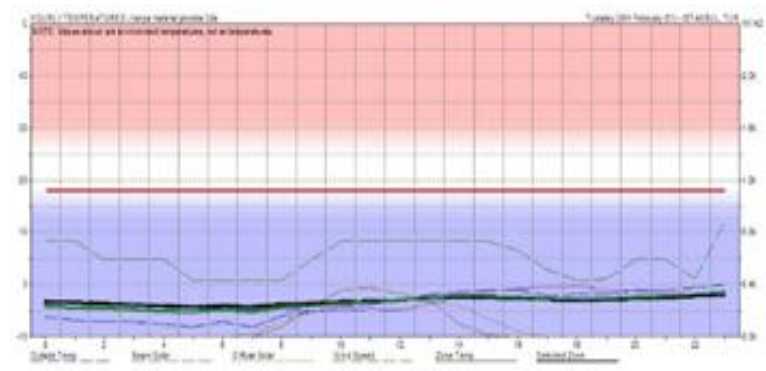

Source: Analysis from Ecotect software (update by the researcher), 2015

Fig.14. Temperature Analysis Result of Mosque Sehzade's Main Room in the Coolest Day in Istanbul

The graph above indicated that the difference of temperature between the condition of closed opening (black line) and opened opening (green line) does not have big delta. This means that the opening in Mosque Sehzade does not influence the room temperature significantly.

The room is still not successful to create comfort because the temperature delta is still around $\pm 23^{\circ} \mathrm{C}$ in the coolest day or climax of coldness at 06:00 in the morning and $\pm 20^{\circ} \mathrm{C}$ in the climax of the heat at 10 pm.

\section{Relation Pattern of Opening with Thermal Comfort based on the Orientation of the Opening}

Following is the table and chart that indicated the relation between opening proportions in each facade orientation towards the fluctuation of temperature in the main room of the mosque building.

The graph above indicate that there is no pattern formed so that it can be said that there is no significant relation between the opening proportion with different orientation in the same building with the internal room radiation temperature. Therefore, it can be concluded that the proportion does not significantly influence the quality of thermal comfort of the building user in Mosque Sehzade. 
Table 2. Data about Orientation, Proportion and Opening Temperature of Mosque Sehzade

\begin{tabular}{lcccc}
\hline $\begin{array}{l}\text { Name of } \\
\text { Mosque }\end{array}$ & $\begin{array}{c}\text { Façade } \\
\text { Orientation }\end{array}$ & $\begin{array}{c}\text { Opening } \\
\text { Proportion }(\%)\end{array}$ & \multicolumn{2}{c}{ Temperature } \\
\hline Sehzade & \multicolumn{3}{c}{$\begin{array}{c}\text { The } \\
\text { Coolest }\end{array}$} & $\begin{array}{c}\text { The } \\
\text { Hottest } \\
\end{array}$ \\
North & 15.3 & 32.6 & -3.85 \\
West & 22.1 & 33 & -3.85 \\
South & 29.1 & 32.6 & -3.85 \\
East & 13.1 & 33 & -3.85 \\
\hline
\end{tabular}

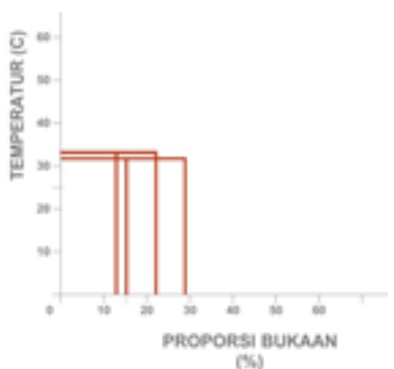

(a)

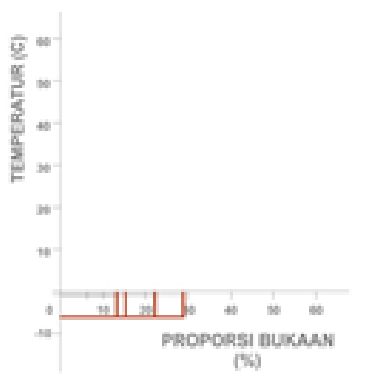

(b)
Fig.15. Proportion Relation of 4 orientation opening with room temperature in Mosque Sehzade in the hottest day of 4 July (a) and coolest day of 20 February (b)

\section{The Great Mosque of Banten}

The Great Mosque of Banten is one of Javanese traditional mosques built in $1566 \mathrm{AD}$ This mosque has the area of $\pm 20000 \mathrm{~m}^{2}$ with the building size of $1368 \mathrm{~m}^{2}$ with the orientation of facing to the west. This mosque has traditional architecture from the materials such as wood column and brick wall plaster with overlapped roof.

The opening in this mosque also use traditional Javanese architecture with big dimension in each of opening unit. It is geometrical and it tend to have similarity in each side of the façade.

\section{Relation Pattern of Opening with Thermal Comfort Based on the Mode of Opening}

The thermal comfort analysis is conducted using Ecotect software Ecotect with the analysis of Hourly Temperature Profile to find thermal comfort based on the average hourly temperature of the internal room. Following is the graph that indicated the difference of temperature in the main room compared to the temperature inside the room without using heating system with standard temperature that indicated $100 \%$ of user comfort in the room.

The black line indicated the condition of the room in The Great Mosque of Banten when the opening is closed. Therefore, the detected temperature is radiation temperature (tmrt). The green line is the measurement of temperature in the main room when the condition of opening is opened. In addition, the red line indicated the temperature when using mode cooling and heating system with efficiency of $80 \%$ with overall heat distribution that produces $100 \%$ comfort. The difference of temperature between opened and closed opening indicated a quite big delta, which is around $\pm 5.0^{\circ} \mathrm{C}$.

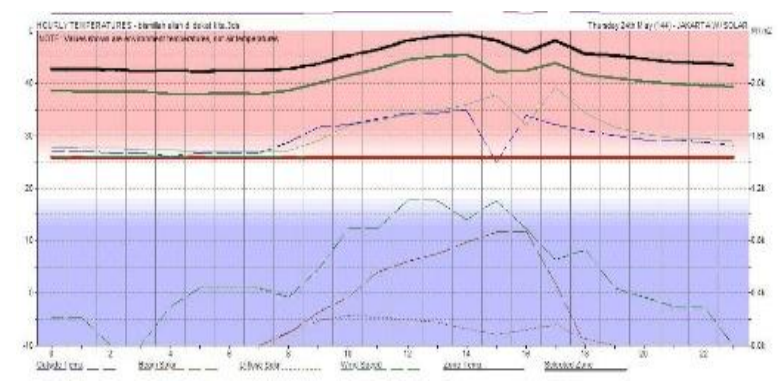

Fig. 16. The Pattern of Average Radiation Temperature in The Great Mosque of Banten

Based on the graph above, it can be seen that the green line is closer to comfort. Thus, it can be concluded that the condition of the room in The Great Mosque of Banten is more comfortable when the opening is opened. Therefore, the temperature inside the room is influenced by outdoor air temperature (ta).

The success of the opening in creating temperature that is close to comfort is still not achieved because the delta of temperature is relatively high, which is around $\pm 19^{\circ} \mathrm{C}$ at $1 \mathrm{pm}$ in the heat climax and $\pm 12^{\circ} \mathrm{C}$ at 5 am.

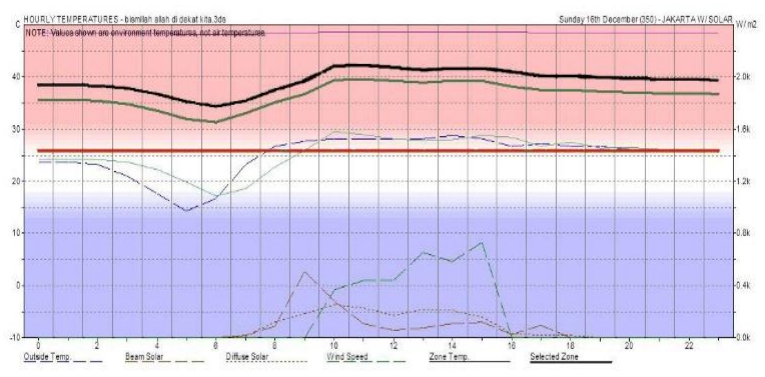

Fig. 17. The Result of Temperature Analysis of main Room in Mosque Agung Banten at the coolest day in different opening mode

The graph above indicated that success level of the building in meeting the comfort standard of the user has not been achieved. The temperature in the room is still too hot compared to the standard condition. The temperature when the ventilation mode is activated is approaching $100 \%$ thermal comfort condition. In other words, the opening in the building façade in The Great Mosque of Banten has good role in achieving thermal comfort. 


\section{Relation Pattern of Opening with Thermal Comfort Based on the Orientation of Opening}

Following is the table and chart that indicates the relation between opening proportion in each façade orientation towards the fluctuation of temperature in the main room of the mosque building.

Table 3. Data of Orientation, Proportion, and Temperature of Opening in Mosque Agung Banten

\begin{tabular}{|c|c|c|c|c|}
\hline \multirow{2}{*}{$\begin{array}{l}\text { Name of } \\
\text { Mosque }\end{array}$} & Façade & Opening & \multicolumn{2}{|c|}{ Temperature (C) } \\
\hline & & & & \\
\hline Agung & & & The & The \\
\hline Banten & & & Coolest & Hottest \\
\hline & North & 6.21 & 40 & 35.2 \\
\hline & West & 7.24 & 40 & 36.67 \\
\hline & South & 0 & 40 & 37 \\
\hline & East & 12.11 & 40 & 37.3 \\
\hline
\end{tabular}

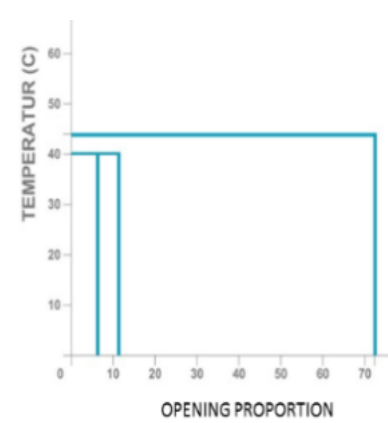

(a)

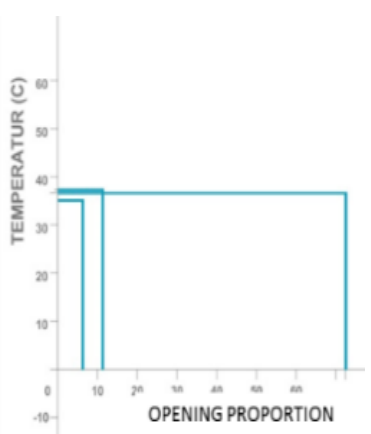

(b)
Source: Analysis of Ecotect software (updated by the researcher), 2015.

Fig. 18. The Proportion Relation of opening with internal room temperature in Great Mosque of Agung Banten in the hottest day 24 May (a) and the coolest day16 December (b)

The graph above indicated the same findings with Mosque Sehzade, that in tropical area, the opening proportion is different in each façade orientation does not significantly influence the room temperature in the mosque.

\section{CONCLUSION}

The Influence of Roof Shape

1. Comparison of Mosque of limasan (pyramid) and dome roof towards the quality of thermal comfort. Mosques with pyramid roof has a more variationnal radiation temperature in each month. Whereas the mosque with dome shading have relatively stable radiation temperature in each month.

Mosque with bigger light opening (Mosque of Mihrima Istanbul and The Great Mosque of Yogyakarta) has a wide range of temperature in the interval of several hours. The Great Mosque of Banten and The Great Mosque of Yogyakarta has the same design pattern. However, it does not make the mosque have comfortable temperature in the same room $\left(20-25^{\circ} \mathrm{C}\right)$. This is not influenced by light and air opening at both mosques. The Great Mosque of Banten has the percentage of comfortable temperature up to $60 \%$, while for The Great Mosque of Yogyakarta is $40 \%$.

2. Spatial comfort pattern of mosque with limasan and dome roof.

Thermal Comfort pattern is influenced by the number, position, size, depth, and openness of the opening. The more open room will expose to the position of hot or warm $\left(25-39^{\circ} \mathrm{c}\right)$. The more closed a room indicated that it will tend to the cool position $\left(7-25^{\circ} \mathrm{c}\right)$. The third one is the determination of opening with intact and wide glass. Small opening that does not use intact glass will influence the temperature of the air in the room. In addition, the deeper the opening, the cooler the room (temperature of $10-25^{\circ} \mathrm{c}$ ).

3. Special thermal behavior resulted from limasan and dome roof.

The shape of limasan and tajuk with triangle made the sun radiation vertically enter the building so that it will make the upper part of the building become homogenously hot. Meanwhile, for dome roof, the sun radiation distribution is not straight and it will be directly diffused so that the radiation will not spread evenly but it will be distributed to area around the dome arc.

The Influence of Opening Proportion

1. Mosque Sehzade in the hottest day of Istanbul City is in the comfort condition of $70 \%$. Whereas, in the coolest day, it is outside the limit of thermal comfort. In other side, The Great Mosque of Banten in the coolest and hottest day in Serang City is in the condition of $70 \%$ comfortable.

2. The opening in Mosque Sehzade in the medium climate in the hottest day of Istanbul City does not have significant influence. This is different with The Great Mosque of Banten that is located in tropical climate area. In the hottest day, the climate will have more influence. The influence is around $\pm 5^{\circ} \mathrm{C}$ to reach thermal comfort of $100 \%$ based on the version of Ecotect.

3. The influence of opening in achieving thermal comfort in mosque with tropical climate is bigger than the influence of opening in the mosque with medium climate

4. The questionnaire result of The Great Mosque of Banten in the hottest day has similarity with the analysis result of mosque using the method of SET. However, it has different result with analysis 
using the method of Ecotect. However, the questionnaire result in Mosque Sehzade in the coolest day showed different result with the analysis using either method of SET or Ecotect. The result difference indicate that there is possibility of confounding factors that cause the result of objective analysis with Ecotect method is not $100 \%$ accurate.

\section{ACKNOWLEDGMENT}

The authors would like to thank all those who have assisted with the completion of this research. Particularly to the Chair of the Department of Architecture UII who has hosted Summer School with Fatih Sutan Mehmed University in Istanbul Turkey so that some of the data was collected. The author also thanked the Dean of FTSP UII for the support of some funds in the completion of this research.

\section{REFERENCES}

Brown (1994). Matahari, Angin dan Cahaya. Bandung: Intermatra.

Direktorat Urusan Agama Islam dan Pembinaan Syariah Direktorat Jederal Bimas Islam Kementrian Agama Republik Indonesia, http://simbi.kemenag.go.id/simas/index.php/profil/mosque/41/, (accessed2015)

Evans, M. (1980). Housing Climates and Comfort. London: Architectural Press

Lippsmeier (1994). Bangunan Tropis. Bandung: Erlangga.

Morris, M. (1980). Buildings, Climate, and Energy. London: Pitman Pub.

Neldy (2011). Mari Belajar Ecotect. http://neldyaja. blogspot.com/2011/11/mari-belajar-ecotect.html (accessed 2015).
Satwiko, P. (2004). Traditional Javanese Architecture and Thermal Comfort, Yogyakarta: Andi Yogyakarta.

Satwiko, P. (2004). Fisika Bangunan 1 Edisi 2, Yogyakarta: Andi Yogyakarta.

Sugini (2013). Handout: Rekayasa Termal Bangunan, Handout, Tidak dipublikasikan, Yogyakarta.

Sugini (2014). Kenyamanan Termal Ruang; Konsep dan Penerapan Pada Desain, Yogakarta, Graha Ilmu.

Susanawiyah (2015). Sejarah Arsitektur Islam, https://www.scribd.com/doc/85809022/SejarahArsitektur-Islam, (accessed 2015).

SNI. (2001). Tata Cara Perancangan Sistem Ventilasi dan Pengkondisian Udara pada Bangunan Gedung, http://staff.uny.ac.id/sites/default/files/ pendidikan/hartoyo-spdmpdmt/perencanaanpendingin.pdf (accessed 2015).

Talarosha, B. (2005). "Menciptakan Kenyamanan Thermal Dalam Bangunan". Journal of Sistem Teknik Industri. 6(3).

Warasfarm (2014). The Great Mosque of Banten: Karya Arsitek Majapahit Hingga Arsitek Menir Belanda, https://warasfarm.wordpress.com/ 2014/10/09/mosque-agung-banten-karya-arsitekmajapahit-hingga-arsitek-menir-belanda/ (accessed 2015).

Widayanti, Suparman \& Sekarsari (2012). Kajian Aspek Pemakaian Energi Pada Sistem Bangunan Tradisional Jawa, Journal of Bangunan Jawa

Wikipedia (2015). Definisi Mosque, http://id.wikipedia.org/wiki/definisimosque, (accessed 2015).

Yildirim, F. Tour of Istanbul In The Footsteps of Mimar Sinan. http://www.kultur.gov.tr/genel/ medya/iltanitimbrosuru-eng/mimarsinan_eng. pdf, (accessed 2015).

Zain (2011). Aplikasi Perancangan Bioklimatik Melalui Software Ecotect dan ESP. https://greenzains.wordpress.com/2011/10/21/aplikasiperancangan-bioklimatik-melalui-softwareecotect/ (accessed 2015). 